\title{
The Gate Belfry of Vysokopetrovsky Monastery With the Church of the Intercession To the Question of the Genesis of the Type
}

\author{
Natalia Merzlyutina ${ }^{1, *}$
}

\begin{abstract}
${ }^{1}$ Scientific Research Institute of Theory and History of Architecture and Urban Planning (NIITIAG), Branch of the Federal State Budget Institution "Central Scientific-Research and Project Institute of the Construction Ministry of Russia", Moscow, Russia

*Corresponding author. Email: merzlutina@mail.ru
\end{abstract}

\begin{abstract}
The following article touches upon the problem of the genesis of one of the new types, which was formed in Moscow architecture at the end of the 17th century. The gate belfry of Vysokopetrovsky Monastery with the church of the Intercession was built during the period of 1690-1694 with the participation of Peter the Great and the Naryshkin family. This monument can rightfully be considered one of the most interesting examples in the architecture of Naryshkin style. It demonstrates the new idea - the gate church and the belfry are combined in one building, turning it into the main architectural dominant of the ensemble. This composition became very popular among the constructors of the Russian monasteries of the 18th - early 20th century.
\end{abstract}

\section{Keywords: Russian churches, gate belfry, Naryshkin style, epoch of Peter the Great}

\section{INTRODUCTION}

The architecture of the era of Peter the Great is one of the brightest artistic phenomena in Russian culture. The architectural style of the end of the 17 th century in the studies of Russian art is called "Naryshkin style" (by the surname of the Naryshkin boyars, who were relatives of the young tsar on his mother's side). The key monuments of the new style have been commissioned by the members of this family. Most famous are the patrimonial buildings and a recognized masterpiece - the Church of the Intercession at Fili, built on the money of the young tsar's uncle - boyar L. K. Naryshkin in 1690-1693. The Church of the Intercession at Fili belongs to the "under the bells" (rus. "izhe pod kolokoly") architectural type, in which the central space of the church is crowned with a belfry. We have already addressed the topic of the revival of the interest to the "under the bells" composition in Russian architecture about 1700 in our previous researches [1]. In this period, in parallel with the active construction of churches of the "under the bells" type, the churches-belfries, in which the dominant role belongs to the belfry, and a small church itself is located within one or two tiers are being erected. In this regard, a fascinating monument is the Intercession

*Fund: This paper was funded by the Program of Fundamental Researches of the Ministry of Construction, Housing and Utilities of the Russian Federation and the Russian Academy of Architecture and Construction Sciences 2020, Research Project 1.2.13.
Church-belfry of Vysokopetrovsky Monastery (16901694), the construction of which is also associated with the Naryshkin family. We have published preliminary conclusions of the research of this monument in the scientific article devoted to the study of the churches of the "under the bells" type and churches-belfries in Russian architecture of the end of the 17 th - beginning of 18 th century [2]. The purpose of this work is to research in more detail the specificities of formation of the composition of the gate church-belfry of Vysokopetrovsky Monastery, related to its construction from the perspective of particular historical aspects, as well as to reveal the mechanisms of interaction between tradition and innovation in the formation and genesis of the type of the gate church-belfry and the importance of this monument for the sacral architecture of Russia of New time.

\section{THE HISTORY OF THE CONSTRUCTION} AND THE GENESIS OF THE TYPE

The first stone fence appeared in Vysokopetrovsky Monastery shortly after the expulsion of the Poles. In the same period, the first Intercession Church, known by documents from the $1630 \mathrm{~s}$, was erected on the north side of the cathedral. The heyday of the monastery fell in the last decades of the 17 th century. The monastery development of this period is directly related to the Naryshkin family, and the struggle for power of the young Tsar Peter I. The Naryshkin estate was located to 
the south of the monastery and was granted to the monastery. In 1682, on the territory of the monastery, two uncles of Tsar Peter I on his mother's side, Ivan and Afanasy Naryshkin, who died during the Streltsy uprising, were buried. In 1684-1685 a new church of the Bogolyubskaya Icon of the Mother of God was erected over their graves, and the altar of Intercession was transferred a little later to a new church over the Holy Gates. In 1690, the monastery Church of St. Peter, the Metropolitan of Moscow, was consecrated again in the presence of the royal family. At the same time, by the decree of Tsar Peter I, the construction of the refectory church of St. Sergius of Radonezh, which was completed in 1694, began. In the same years, the construction of the Intercession Church with a belfry over the Holy Gates of the monastery was conducted [3] ("Fig. 1"). According to some sources, the Church of the Intercession has been already built by 1690 . It is known that the German clock on the belfry was set by the master Ivan Zakhariev in 1702. The bells were located in the third tier, and the fourth was "idle" [4]. Vasily Iosifovich Tekutiev has headed the monastery construction during these years, according to the tsar's order. Later his place was taken by his son Mikhail Vasilievich Tekutiev. For the first time, the Church of the Intercession, "over the gates, under a belfry," is mentioned in the "Description of the Monastery of 1694" [5]. In the works on this topic, the construction is usually dated 1690-1694 [6]. Its erection was conducted by the archimandrite Job, who managed the monastery in 1689-1694. The author of several books about Vysokopetrovsky Monastery - the Archimandrite Gregory (Voinov) - mentions Job as one of the "Russian pastors loved by Peter the Great" [7].

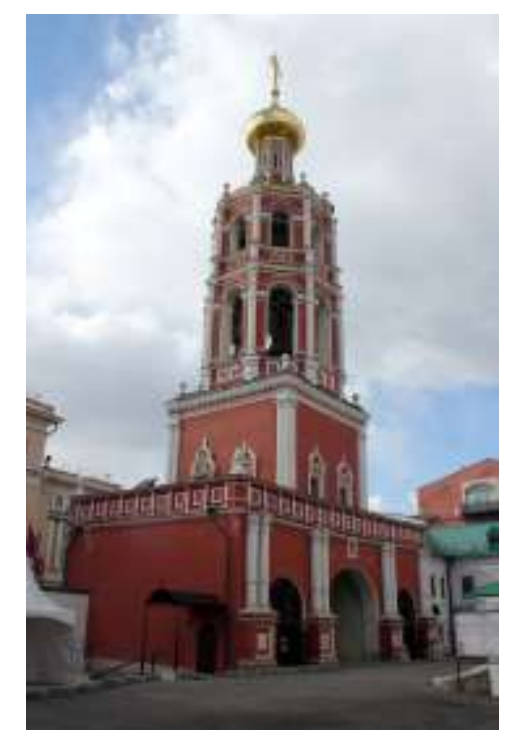

Fig. 1. The gate belfry with the Church of the Intercession of Vysokopetrovsky Monastery. 1690-1694.

Thus, the active construction, commissioned by Tsar Peter and his relatives - the members of the
Naryshkin family by the very end of the 17th century, has turned Vysokopetrovsky Monastery into an oasis of the churches of the new Naryshkin style. In the architecture of the Refectory Church of St. Sergius of Radonezh, the orientation on similar buildings in Simonov and Novodevichy Convent, as well as in the Trinity-St. Sergius Lavra is noticeable. It is a traditional pillarless type of a five-domed church, decorated with a new system of white-stone elements. The architecture of this monument is, to some extent derivative, and follows the already established typology and imagery that appeared in the last years of the reign of Tsar Fyodor Alexeevich and the regency of Tsarevna Sophia. The idea to decorate the traditional pillarless church with a new decor was born in a circle of Miloslavsky [8]. The reconstruction of an ancient cathedral of Peter, the Metropolitan of Vysokopetrovsky monastery and its solemn consecration in the presence of both tsars Peter and Ivan, gave rise to the appearance in the architecture of the turn of the 17th-18th centuries of a number of patrimonial churches of innovative typology with the Renaissance centrifugal eight-petal plan.

In the Intercession Church "under the bells" over the Holy Gates, an entirely new type of a gate churchbelfry, which used the complete arsenal of the forms of the Naryshkin style, has finally formed. The gate churches have been known in Russian architecture since the pre-Mongol period. The history of belfries in Russian architecture has also gone a long way by the end of the 17th century. In the Late Middle Ages, the monastery gate churches, placed across the central axis from the entrance and having a belfry attached to one side, can be found. A vivid example in the architecture of the middle of the 17th century is the Gate Church of the Kazan Icon of the Mother of God of the Trinity Monastery in Murom (1648-1652) with a belfry attached to it sometime later (1658), built on the money of a merchant Bogdan Tsvetnoy [9]. Also, in the 1650s, the only gate church-belfry known to us - the Gate Belfry with the Church of St. Gurias, Samonas and Abibus, constructed on the money of the merchant Gury Nazaryev at the church of the Nativity - was erected [10] ("Fig. 2"). This monument is a splendid example of its time. It consists of a three-span base, rectangular volume of the church with a covered promenade, and a belfry with towers in the corners, topped with a large tented roof with several rows of dormer windows. It is important to emphasize that the Yaroslavl church-belfry was erected over the gates of the parish church ensemble, which previously had a fence. In its volumetric and spatial composition, the image of the Spasskaya Tower of the Moscow Kremlin is remotely guessed. Thus, in the middle of the 17th century, architects began to actively search for a new image of the gate church-belfry. 


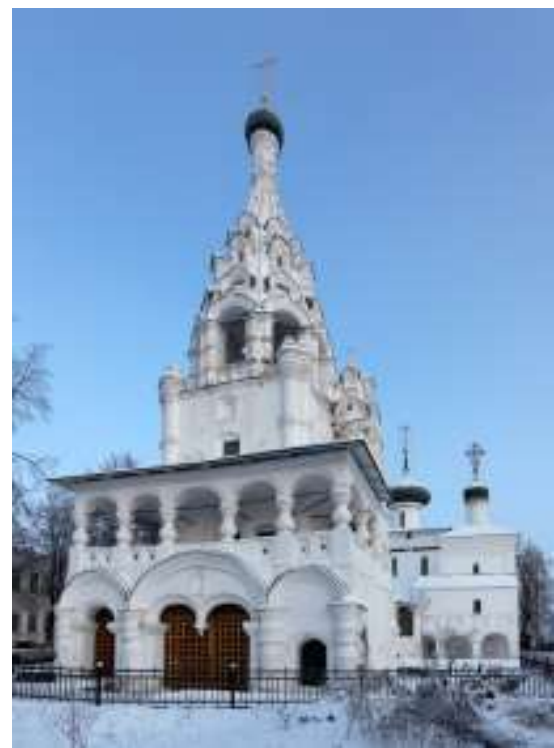

Fig. 2. The gate belfry with the Church of St. Gurias, Samonas, and Abibus at the Church of the Nativity of Christ in Yaroslavl. The middle of the 17 th century.

The masters who built the church-belfry of Vysokopetrovsky Monastery were wholly immersed in their era. Only the three-span Holy Gates, adopted by the architects of the Naryshkin style from the previous period, remained from the traditional scheme. Above, there is a small rectangular volume of the church without an apse, surrounded by an open promenade gallery decorated with large square depressions - a characteristic compositional feature for the monuments of the Naryshkin style. The windows of the church are decorated with casing with open crowns, which has also become the hallmark of the novel system of decoration. Above, two octahedral belfry tiers equal in size, and the dome on the open faceted drum grow. In order to improve the sound, there is an amplification opening in the vault of the upper tier of the belfry. One can get to the belfry by a narrow spiral staircase in the northwest corner of the Church of the Intercession. Twin columns flank the arched spans. At the corners of the cube, there are three columns, with one at the corner of each tier of the belfry.

Considering the belfry of Vysokopetrovsky Monastery as a bright example of a new style, experts nevertheless note its secondary importance in relation to the belfry of the Novodevichy Convent [11]. The researchers paid more attention to the latter and considered it to be a recognized masterpiece of a new style [12]. Not wishing to belittle the merits of the Novodevichy Belfry, let us note the simpler design chosen for its construction. This monument obviously draws the viewer's attention with its similarity to the belfry of Ivan the Great. The difference is, first of all, the decoration itself. Undoubtedly, the architectural figurativeness of the high tiered belfry was influenced, apparently, by the Dutch models. So, M. N. Mikishatiev wrote about the similarity of the volumetric-spatial organization of the Yaroslavl belfry of the Predtecheskaya Church in Tolchkov and the Amsterdam Montelbaanstoren tower erected at the turn of the 16th-17th centuries [13]. The researcher proved that during the reconstruction of the Corner ( «Duck») Tower of the Trinity-Sergius Lavra, two compositions by the Dutch architect Peter Post - the Maastricht Town Hall Tower, and the Swanenburgh Tower had been used [14]. In the case of the gate church-belfry of Vysokopetrovsky Monastery, we are dealing with a much more complex architectural solution than in the Novodevichy Convent, which causes allusions with the Spasskaya Tower of the Moscow Kremlin (1491, Pietro Solari; the tented roof completion (1624-1625) by Christopher Galloway), also located above the Holy Gate and having an open bypass gallery and a tier of bells, as well as Dutch towers of the 17th century. At the same time, today it is not possible to specify one exact model used in the construction, and most likely, the appearance of the gate church-belfry was "composed" by commissioners based on various architectural examples.

The idea of the gate church-belfry proved to be quite innovative. Located above the Holy Gate, on the same axis with the Cathedral of the Bogolyubskaya Icon of the Mother of God, it emphasized the sacredness of the main entrance and served as a beacon for the pilgrims [15]. At the same time, the belfry was an important town-planning dominant feature, compensating for the absence of a traditional large fivedomed cathedral in the monastery. The raised tiny gate church is still easily "readable" from afar. The conventional scheme has been perfectly combined in this monument with an innovative solution. And the design can be considered innovative due to the creation of a new composition of two octagons on a rectangular base, and the very idea to connect the Holy Gate of the monastery, the gate church and the belfry on one vertical axis.

\section{Gate ChURChES-BELFRIES IN THE RUSSIAN ARCHITECTURE OF THE 18TH - EARLY 20TH CENTURIES}

It is traditionally believed that the belfry of Vysokopetrovsky Monastery served as the model for the belfry of Pafnutievo-Borovsky Monastery, erected at the ancient refectory church of the Nativity of Christ in the late 17th century ("Fig. 3"). In this case, we are talking about the very form of the belfry, which represents two equal in size open octahedral tiers of bells on a square base. The image of the monastery belfry influenced the urban and rural churches erected at the end of the 17th century, the general composition of which includes the belfry. Examples are the belfry of 
the Moscow Church of All Saints na Kulichkakh ("Fig. 4") and the belfry of the Trinity Church in Dedinovo, built in the fishing village on the money of a Moscow merchant N. F. Shustov (1696-1700) ("Fig. 5"). These monuments replicate the general volumetric composition of the belfry, which consists of two tiers of octagons, placed on a rectangular base, and topped with a head on a faceted drum. The upper octagon in both cases represents the tier of the bells, and the lower one is blank. These examples show that the image of the Vysokopetrovskaya belfry influenced the monuments of its time in terms of the volumetric and spatial composition.

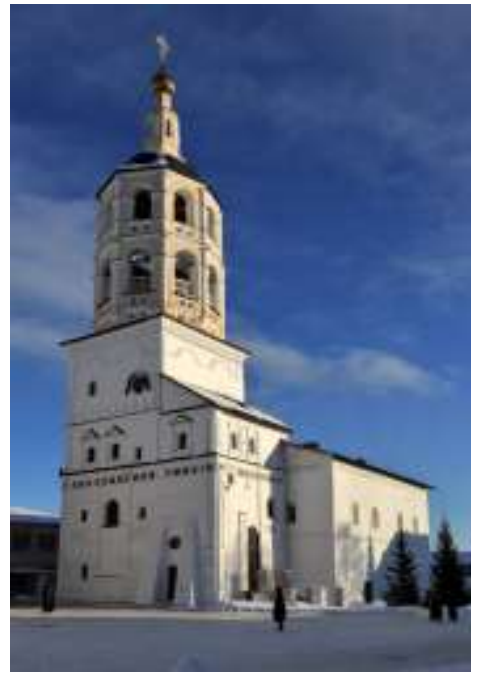

Fig. 3. The belfry at the ancient refectory of the Church of the Nativity of Christ of the Pafnutievo-Borovsky monastery. The end of the 17 th century.

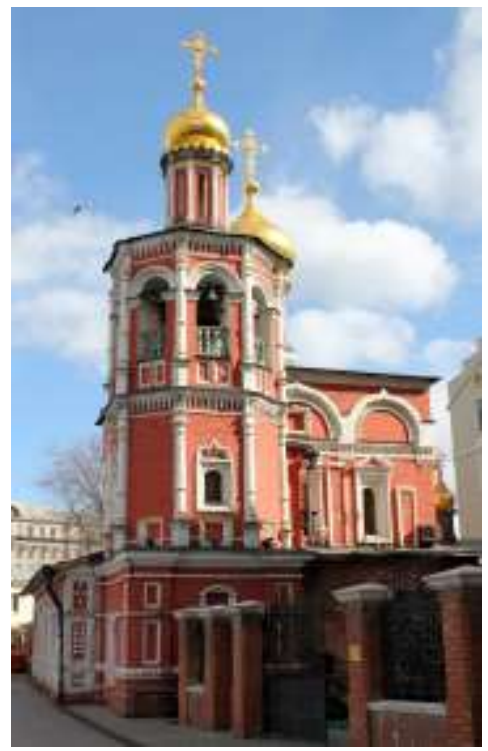

Fig. 4. The Church of All Saints na Kulichkakh in Moscow. The belfry. The end of the 17 th century.

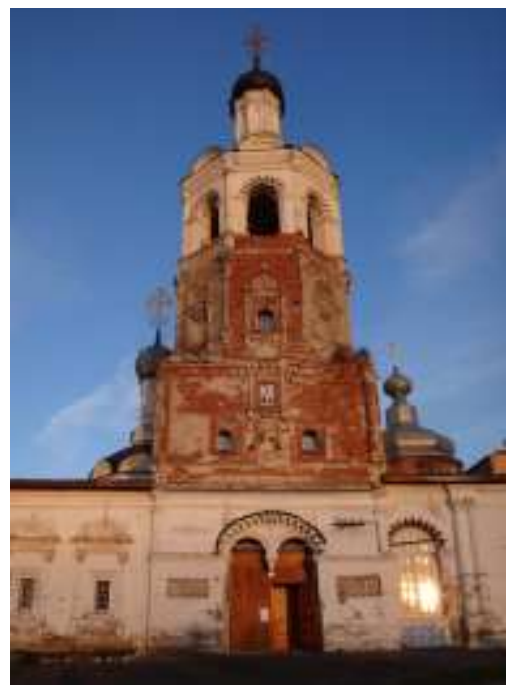

Fig. 5. The church of the Trinity in Dedinovo (Moscow region). 1696-1700.

At the same time, the very theme of the gate churchbelfry is directly continued in the monuments of Naryshkin style, in particular, in the gate belfry, commissioned by the Lopukhins at the turn of the 17th 18th centuries in a small Spaso-Preobrazhensky Monastery in the village of Podkopaevo near Meshchovsk (Kaluga region). The church under the belfry was consecrated in 1701 in the name of the Metropolitan of Moscow - St. Alexiy ("Fig. 6") [16]. The monument combines the features of Uzorochye and Naryshkin styles. Typical for the earlier period of Moscow architecture, the hipped belfry is erected above a small rectangular church with a semicircular altar raised above a three-span gate. At the same time, the tented roof has a double tier form, and the church is surrounded by a small open gallery-promenade, which is typical for the Naryshkin style. The top of the gallery, the cube, and the parapet of the tier are girded with large square depressions, and the facades are decorated with white stone elements, which include details typical for both old and new styles. Thus, the three-partite completion of the window adjoins the open top of the portal, which also testifies to the awareness of masters of the best examples of the Naryshkin style, and possibly of the monuments of Vysokopetrovsky Monastery [17]. 


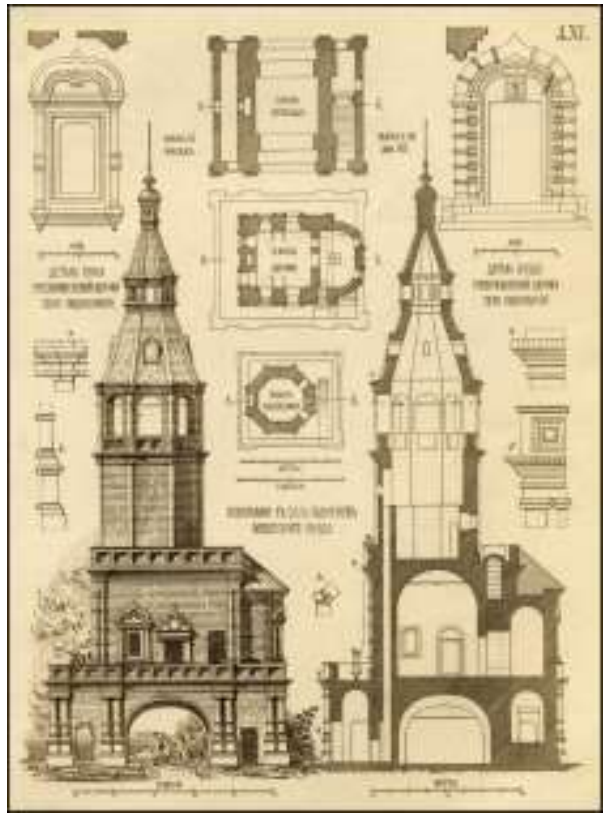

Fig. 6. The gate belfry with the Church of St. Alexiy, the metropolitan of the Moscow Transfiguration Monastery in the village of Podkopaevo near Meshchevsk (Kaluga Region). Around 1700. [15].

The idea of the gate church-belfry, so beautifully decorated in Vysokopetrovsky Monastery, was further developed in the New Time. We meet it in the era of Petrovsky Baroque. An example is the gate belfry with the church of the Tikhvin Icon of the Mother of God over the northern gate of the Don monastery (17131714, architect I. P. Zarudniy (?)) and in the Anninsky Baroque period - for example, the belfry with the church of St. Simeon Stylites above the gate of the Don monastery (1731-1732). There are wonderful examples of monastery gate churches-belfries, in the period of the mature Baroque as well, in particular, the gate belfry with the Church of St. Sergius of Radonezh of the Novospassky Monastery (1759-1785, architect I. P. Zherebtsov). An example of a gate church-belfry, erected in the Classicist style, is the Spassky church with the belfry above the gate of the Boris and Gleb Monastery in Torzhok (1804-1811, designed by the architect N. A. Lvov) or the gate belfry with the Church of the Three Holy Hierarchs of the Vysotsky Monastery (1831-1840, designed by E. G. Milyutin) in Serpukhov. Similar monuments are actively built in the era of historicism: the belfry over the Holy Gates with the Church of the Assumption of the Bogolyubsky Monastery near Vladimir (1841); the gate church-belfry with the Altar of St. Alexiy of the Strastnoy Monastery in Moscow (1849-1855, M. D. Bykovsky, destroyed). The most recent example of the embodiment of the idea of the gate church-belfry in Russian sacral architecture is the belfry with the church of St. Photius, the Metropolitan of Moscow over the gates of the Guslitsky Spaso-Preobrazhensky Monastery, erected in 1914-
1917 in the Russian style. Clock mechanisms have been installed on many similar monuments, as well as on the church-belfry of the Intercession of Vysokopetrovsky Monastery. From the list of the monuments mentioned earlier, it can be seen that the idea of the monastery church-belfry, so brilliantly decorated, in the work of Vysokopetrovsky Monastery, has been further developed during two centuries and embodied in a number of remarkable monuments of different stylistic directions.

\section{Conclusion}

The study of the belfry with the church of the Intercession over the Holy Gates of Vysokopetrovsky Monastery leads us to some important conclusions. The search for a new architectural type begins in the middle of the 17th century. The very idea of the gate churchbelfry over the monastery gate, finally formed in the circle of the young Tsar Peter I and the boyars of Naryshkin, emphasized the traditional for Russian sacral architecture symbolism of the Holy Gates of the monastery, clearly demonstrating the words of the Lord: "I am the gate. Whoever enters through me will be saved" (John 10: 9). In our opinion, its appearance could have been influenced by the architecture of the Spasskaya Tower of the Moscow Kremlin, as well as the images of Dutch belfries known to Russian engravers.

The Pokrovskaya Gate Church-belfry of Vysokopetrovsky Monastery erected in the early 1690s is a key monument which, on the one hand, influenced the architecture of the Naryshkin style itself. Masters noted a volumetric and spatial composition, consisting of two equal in size octagonal tiers on a rectangular base, of which one or both tiers are dedicated to the bells. On the other hand, starting with the monuments of the Naryshkin style itself, the new architectural type was further embodied in many gate churches-belfries of Russian monasteries of New time. In the ensembles of the 18th - early 20th centuries, the belfry is often moved from the monastery to its Holy Gate, becoming an important landmark for the visitors of the monastery. The church, arranged there, emphasizes the sacral nature of the act of entering the monastery through the Holy Gate. Thus, in the studies of the monument of our interest, we can speak separately about the impact of its volumetric-spatial composition on the architecture of the Naryshkin style and the creation of a new architectural type that has easily expanded the stylistic framework of its time.

\section{References}

[1] N. Merzlyutina, "To the Question of the Origin of the "Under the Bells" Composition in Patrimonial Churches of the End of 17th Century (K Voprosu O Proishozhdenii Kompozicii "Izhe 
Pod Kolokoly" V Votchinnyh Hramah Konca 17th Veka)" Architectural Heritage, vol. 71. Moscow, 2019, pp. 89-102 [in Russian].

[2] N. Merzlyutina, "The Research of the Churches "Under the Bells" and the Churches-Belfries in the Russian Architecture of the Late 17th - Early 18th Century: Traditions and Innovations (Preliminary Ideas)" Proc. 2019 Int. Conf. of Architecture: Heritage, Traditions and Innovations (AHTI 2019), vol. 324. https://doi.org/10.2991/ahti-19.2019.22 [in Russian].

[3] Vysoko-Petrovsky Monastery (Vysoko-Petrovskiy Monastyr) The Monuments of the Architecture of Moscow, vol. 2, White City (Pamyatniki Arhitektury Moskvy. Tom 2. Beliy Gorod), No 129. Moscow, 1989, pp. 180-188 [in Russian].

[4] Grigoriy (Archimandrite), Vysokopetrovsky Monastery. Moscow, 1873, pp. 22-23 [in Russian].

[5] B. P. Dedushenko, "On the History of the Ensemble of the Moscow Vysokopetrovsky Monastery (K Istorii Ansamblya Moskovskogo Vysoko-Petrovskogo Monastyrya)" Old Russian art (Dreverusskoe Iskusstvo). Moscow, 1964, pp. 253-271 [in Russian].

[6] E. E. Springis, "Vysokopetrovsky Monastery (VysokoPetrovskiy Monastyr)" The Orthodox Encyclopedia (Pravoslavnaya Enciklopediya), vol. 10. Moscow, 2005, pp. 7175 [in Russian].

[7] Grigoriy (Archimandrite), The Lists of the Parsons of the Moscow Vysokopetrovsky Monastery, and Tombstones (Spiski Nastoyateley Moskovskogo Vysokopetrovskogo Monastyrya, Ego Zhe Nadgrobnye Pamyatniki). Moscow, 1874, pp. 3-4 [in Russian].

[8] N. Merzlyutina, Traditional Pillarless Churches of the "Naryshkin" Style (Tradicionnye Besstolpnye Hramy "Naryshkinskogo" Stilya). Abstract of the Dissertation for the Degree of Candidate of Art History. Moscow, 2002, p. 26 [in Russian].

[9] N. A. Bespalov, Murom: Monuments of Architecture and Art (Murom: Pamyatniki Arhitektury i Iskusstva). Moscow, 1990, pp. 28-32 [in Russian].

[10] T. A. Rutman, Churches and Holy Places of Yaroslavl (Hramy i Svyatyni Yaroslavlya). Publishing House of Alexander Rutman, 2005, pp. 145-151 [in Russian].

[11] M. N. Mikishatiev, "Naryshkin Style" and Russian Architecture of the Late 17th Century. To the Problem of the "Breaking Points" in Social and Artistic Development ("Naryshkinskij stil" i Russkaya Arhitektura Konca 17th veka. K Probleme "Perelomov" v Obshchestvennom i Hudozhestvennom Razvitii)" Arhitektura v Istorii Russkoj Kultury, Iss. 6, Turns of Ages. Moscow, 2005, pp. 196-236 [in Russian].

[12] O. V. Azarova, "The Bells of Novodevichy Convent. The History of the Forming and Its Current State (Kolokola Novodevichego Monastyrya. Istoriya Formirovaniya Podbora i Ego Sovremennoe Sostoyanie)" Restoration and Research of Cultural Monuments (Restavraciya i Issledovanie Pamyatnikov Kultury). Moscow, 2016, Iss. 8, pp. 74-86 [in Russian].

[13] M. N. Mikishatiev, "The Netherlands and Russia: on the Issue of the Reflection of Cultural Contacts in the Russian Architecture of Late 17th - Beginning of 18th Century (Gollandiya i Rossiya: K Voprosu Otrazheniya Kulturnyh Kontaktov V Russkoj Arhitekture Konca 17th - Nachala 18th Veka)" Arhitektura Mira, Iss. 2. Moscow, 1993, Ill. 1, 2 [in Russian].

[14] M. N. Mikishatiev, "Early Monuments of Peter's Epoch (Rannij Pamyatnik Petrovskoj Ehpohi)" Problemy Sinteza Iskusstv i Arhitektury, Issue 14. Leningrad, 1983, pp. 18-24 [in Russian].

[15] I. L. Buseva-Davydova, "The Development of the Composition of Russian Monasteries of the Classicism Era (Razvitie Kompozicii Russkih Monastyrei Epohi Klassicizma)" Matvey Fedorovich Kazakov and the Architecture of Classicism (Matvei
Fedorovich Kazakov i Arhitektura Klassicizma). Moscow, 1996, pp. 126-134 [in Russian].

[16] M. T. Preobrazhensky, Monuments of Old Russian Architecture within the Kaluga Province (Pamyatniki Drevnerusskogo Zodchestva v Predelah Kaluzhskoi Gubernii). Saint Petersburg, 1891, pp. 72-73, Table, L. 11 [in Russian].

[17] E. A. Shorban, ""Naryshkin Baroque" in Abandoned Places of the Kaluga Region («Naryshkinskoe Barokko» v Zabroshennyh Mestah Kaluzhskoi Oblasti)" Priroda. Moscow, 2008, No 7, pp. 56-62 [in Russian]. 